\title{
Research on the Training Path of Double Innovation Talents for the Professional Certification of Engineering Education
}

\author{
Hui Jiang ${ }^{1, a}$ and Min Liü ${ }^{1, b}$ \\ ${ }^{1}$ College of Automobile \& Architectural Engineering, Beihua University, China \\ a282521871@qq.com, ${ }^{b} 2632594364 @ q q . c o m$
}

Keywords: Engineering education professional certification; Transportation; The path; Innovative undertaking

\begin{abstract}
As one of the important contents of undergraduate teaching quality and teaching reform in China, the professional certification work of education has been paid great attention. Clear meaning to develop international engineering education professional certification is presented in this paper, on this basis, analyzing the urgency that transportation professional conduct engineering education professional certification, and put forward from the rebuild teacher's responsibility, double gen concept into the curriculum, students assessment and examination results reflect the graduation requirements of such aspects as establishing transportation professional innovative entrepreneurial talent training path.
\end{abstract}

\section{Introduction}

Since the 21 st century, the theory and practice of higher education quality assurance has become a hot and focus issue for governments, education researchers and the public in the world. Engineering education professional certification in China started in 2006, professional transportation is one of the first to start the professional by the end of 2017, 395 transportation professional points in our country, in which abount14 points through engineering certification, the percent of pass is only $3.54 \%$, slightly higher than the national all engineering professional certification pass rate of $3.3 \%[1-2]$. At the same time, colleges and universities rely on their own disciplinary advantages and resource platforms, and in the transportation professional setting up the humanities, partial management, partial industrial engineering, partial traffic science. At present, the 14 universities that have passed the certification are also limited to the traditional high level professional advantage colleges, and the overall development is relatively backward. As the government related department and ngos, engineering education professional certification work in colleges and universities carry out and implement step by step, establish and improve the international equivalence of engineering education professional certification system has reached broad consensus[3].

\section{Carry out the Significance of Education Professional Certification}

The national medium and long-term plan for reform and development of education (2010-2020) clearly states that improving quality is the core task of education development, which is the basic requirement of building higher education power. And engineering education accreditation is the key to the students' engineering ability and practice ability to the quality of the assessment, promote the engineering education professional certification[4]. for deepening the reform of our country's engineering education and innovative entrepreneurial talent training, have very important significance, as shown in figure 1, mainly includes the following aspects.

Define the training objectives of professional personnel for transportation. The core idea of engineering education professional certification for talent cultivation is output oriented, and its focus is on students' cultivation of engineering practice ability and knowledge application ability. Therefore, the training goal of the innovation and entrepreneurial talents of transportation professional should first be based on the cultivation of application-oriented talents with professional skills to meet the current development needs of the society; Secondly, it is the core of cultivating entrepreneurial talents with innovative ability to meet the needs of talents with core 
competitiveness[5-7].

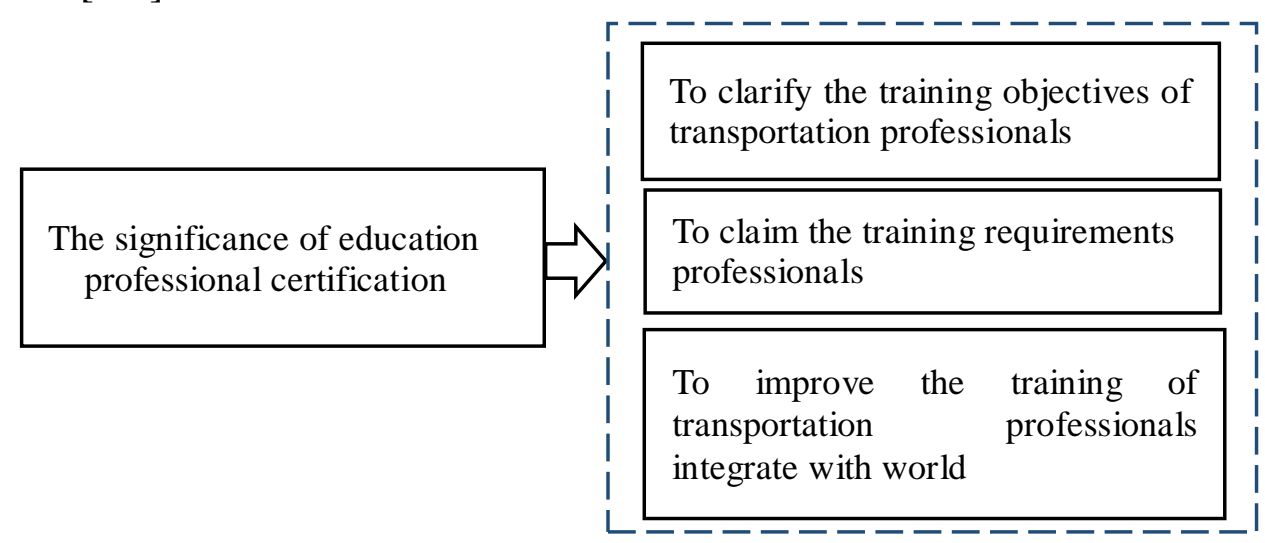

Figure 1 The significance of education professional certification.

Put forward new requirements for the training of professional personnel in transportation. At the present stage, the engineering education major focuses on two abilities, namely the ability of engineering practice and the comprehensive application of multidisciplinary knowledge, in talent cultivation. From this perspective, higher education needs to shift from traditional "teacher" to "student" to some extent. Higher education to students after graduation to engage in professional work as the direction, for the students to meet the needs of future work and social development to develop transportation professional talent training scheme, and thoroughly implement student-centered teaching design scheme and implementation of the teaching idea of teaching activities.

Promote the cultivation of professional personnel in transportation to the world. Engineering education professional certification has realized the mutual recognition among graduates of the countries and institutions that have participated in the certification, which has greatly promoted the international exchange of students in colleges and universities[8]. In the engineering education professional certification standards, transportation professional graduate education in our country can be recognized by foreign universities and foreign enterprises, which will promote the internationalization of China's colleges and universities graduates flow.

\section{The Urgent Analysis of Education Professional Certification for the Transportation Specialty}

At present our country is in a high speed in the process of modernization construction, transportation, logistics, and the government planning department of transportation professionals demand is higher and higher, but subsequently for professional skills, the ability to ask for more and more is also high[9].Based on education professional certification standards, students are required to have the ability of innovative practice and multi-disciplinary knowledge, while mastering basic professional skills.

Improve students' engineering practice ability. At present, the cultivation of engineering practice ability of students majoring in transportation in Beihua University is mainly through two aspects: one is the on-campus experiment and the other is the practice outside the school. Campus experiment from the traditional static form is given priority to with watching, to let the students hands-on dynamic form, the scene teaching, tear open outfit increased, the proportion of experimental courses in the experiment teaching is more comprehensive design experiment and innovative experiment, cultivate students' ability and analysis ability to solve real problems[10].Practice outside the school, let the students take the internship, so that they can complete the study in the real work environment. Besides, it also includes graduation practice and course design, and can prepare graduation design or thesis title based on the actual enterprise project, so as to realize real landing training.

Promote the improvement of students' comprehensive utilization of multidisciplinary knowledge. In order to strengthen innovation and entrepreneurship education, school colleges 
encourage teachers to instruct students to participate in innovation experiment programs of college students and students' scientific and technological innovation activities. Relying on various professional research teams, students are encouraged to join and stimulate students to get into academic atmosphere as soon as possible. Rely on professional laboratory to realize all-day open activities, encourage students to enter the laboratory in spare time to stimulate learning enthusiasm.

The social practice platform provided by the school mainly includes production practice, graduation practice and club activities. For example, the school has set up a number of student societies, and huateng motorcade represents the school's participation in the national automobile competition every year.

The above ability training is in line with the training goal of contemporary students and will benefit students' future competition environment.Therefore, it is more urgent to carry out engineering education professional certification for transportation major.

\section{Engineering Education Professional Certification of Transportation Professional "Double Innovation" Talent Cultivation Paths}

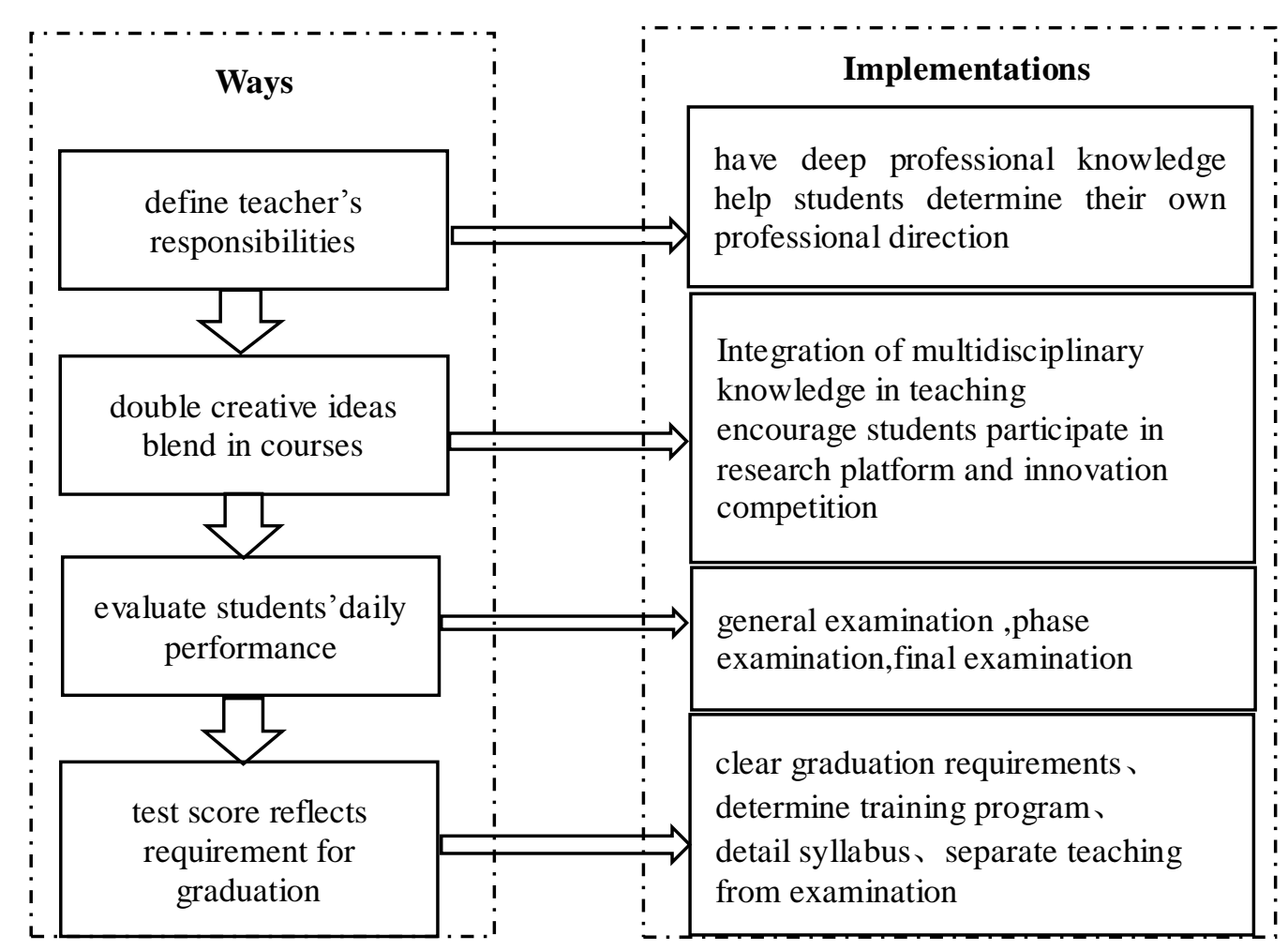

Figure 2 The training path of "double innovation" personnel training in the background of education professional certification.

As shown in figure 2, the training path of the "double innovation" talent cultivation path of the "double innovation" talent cultivation path of the engineering education professional certification is included in the following aspects.

Reconstructing teachers' responsibilities. In the teaching process, full-time teachers should be able to play a dual role. First of all, teachers should have deep professional knowledge and cultivate students' professional knowledge skills. Second, teachers should help students to objective and rational choice conforms to the characteristics of professional direction, and guide students to realize what they have learned in the teaching content in the position and role of the professional knowledge system, and cultivating their independent thinking ability. Engineering education professional certification students must first be applied talents, that is to meet the needs of social employment.At the same time, students should have a certain degree of 
innovation and entrepreneurial ability, and can become research or entrepreneurial talents to meet the development needs (employment or postgraduate entrance examination) after graduation.

The idea of double innovation is integrated into the curriculum. We will carry out a new teaching and training mode, build a complete professional curriculum system, and make innovative and entrepreneurial education for students, so that they will receive systematic professional study[3,5]. First of all, in the course of teaching, education, which has the characteristics of interdisciplinary transportation, enables students to have a complete professional knowledge structure system, which can integrate multidisciplinary knowledge. Second, with the help of teachers' scientific research project and all kinds of innovation and entrepreneurship competition, let students participate, to fully arouse the enthusiasm of students to participate in scientific research, to participate in the competition, in the process of implementation of teachers with students, higher level with the lower echelons. Use of north university of China transportation professional scientific research team of the existing three projects and all kinds of competition, the research direction and the teacher gives necessary guidance, let the students put forward research ideas and solutions, training students to discover problems, analyze and solve problems.Further develop the students' spirit of cooperation and team consciousness, so as to provide a systematic teaching platform for innovative entrepreneurial talent cultivation.

Daily performance evaluation of students. Evaluation of normal performance.The performance evaluation takes the form of the hall. Assessment indicators include attendance, classroom questions, keynote speeches, in-class quizzes and group discussions. The attendance rate of the students is assessed by the college and the teachers, and the other indicators are evaluated by the teachers[9]. The performance of the assessment will be calculated according to the different attributes of the course.

Assessment in stages.The stage assessment focuses on the process assessment, and adopts the diversified assessment form, such as the closed volume, open volume and half open volume; Written examination, oral examination, defense, thesis, case, etc., encourage students to think a variety of answers, and cultivate innovative ability. Teachers from the training of students to acquire theoretical knowledge, practical skills, comprehensive quality, can adopt flexible and diverse assessment forms, and pay attention to the students personalized ability examination.

Final assessment.The final examination of students majoring in transportation and transportation is evaluated mainly through the examination (or examination) of the theoretical courses. Pay attention to the important basic theory, knowledge examination content, content of the organic combination of theory and practice of application of the inspection, and actively improve the quality of examination paper proposition, strive to grade distribution is normally distributed.

Examination results reflect graduation requirements.First, the graduate knowledge and ability factors that meet the requirements of professional certification are clarified. In the process of the cultivation of the concrete, through the curriculum, practice, graduation design and technology lectures and humanistic quality, students' social activities such as link to ensure the realization of students' knowledge, ability and quality.

Second, in order to guarantee to fulfill the requirements of training goal, in the talent training scheme set up general compulsory education in the talent training scheme, general education elective courses, professional basic required courses and professional elective courses, professional required courses, professional electives, based on practice link and other kinds of courses.Students shall obtain all credits of each teaching link within the length of schooling specified in the school.

Thirdly, according to the teaching goal, make a detailed syllabus for each course, and make clear the teaching content, achievement composition of the course. According to the curriculum test paper, and according to the course category to adopt multichannel assessment method.

Fourthly, the basic curriculum of general knowledge is subject to examination and separation. Professional basic and professional compulsory courses are arranged according to the syllabus of the course, and the course is conducted by teachers in combination with projects, cases and subjects. 
Three sets of test papers are required for each course, and the repeat rate of the test paper for three consecutive years is no more than $30 \%$.

Fifth, the practice course to filter through a complete set of management system, professional practice teaching resources is the key to effective application, to realize in practice teaching, not only in form. Therefore, the construction and effective implementation of quality practice teaching resources teaching is the key link in the practical teaching of transportation. Students are required to complete the internship journal and internship report. Assessment method for internship practice course made clear, report about internship, graduation design, off-campus practice activity with clear evaluation criteria, evaluation of these are usually performed by teachers with college.

Sixth, extracurricular innovation credits require students to combine the university-level, provincial-level and national-level university students' innovation experiment program and teachers' scientific research projects; Actively encourage students to participate in various competitions and replace the corresponding innovation credits according to the achievements obtained.

Based on engineering education professional certification of professional transportation innovative entrepreneurial talent training, enable students to systematically study the transportation professional class knowledge, at the same time provide an innovative entrepreneurial thinking space for the students, stimulate students' innovation consciousness, make its thinking potential fully digging, for training students' entrepreneurial ability to lay the comprehensive quality.

\section{Conclusion}

The professional certification of education has played a significant role in promoting the professional construction and development of colleges and universities. Based on the concept of engineering education professional certification and standard as the guiding ideology to cultivation of transportation professionals, so that students in a professional transportation knowledge learning at the same time, accumulated a certain amount of knowledge, innovative undertaking training innovative entrepreneurial awareness, eventually become the conforming to the requirements of the society.

\section{Reference}

[1] J.Lin: Higher Engineering Education Research.Vol. (2017) No.2, p. 74. (In Chinese)

[2] L.Y. Jiang and J.Chen: Journal of Zhejiang industrial University(social science edition). Vol. (2014), No.03, p.76-79 (in Chinese)

[3] Silva A N:engineering Education and Practice. Vol. (2012), No.4, p305-313

[4] M.H.Li: Journal of Changchun University.Vol. (2012), No.01, p.25-31 (in Chinese)

[5] Y. Bai: Analysis of China's Petroleum and Chemical Economy. Vol. (2009), No.05, p.125-131 (in Chinese)

[6] Koehn E E. Journal of professional issues i. Vol. (2014), No.2, p.77-83

[7] W.F.Zhou: Chinese adult education. Vol. (2008), No.12, p.35-41 (in Chinese).

[8] Y. Li: Henan chemical industry. Vol. (2013), No.30, p.78-81 (in Chinese).

[9] W.P.Jia: Experimental Technology and Management. Vol. (2015), No.1, p.16-19 (in Chinese)

[10] Davis S: engineering Education and Practice. Vol. (2013), No.1, p51-58 